NEWS

\title{
222 NIH grants: 22 researchers
}

A whopping 200 scientists received six or more grants each from the US National Institutes of Health (NIH) in 2007, according to data analysed by Nature. One principal investigator was awarded 32 grants, the data reveal, and many others got eight or nine.

The amounts awarded to some of these grandee grantees held some surprises too. Robert Sherwin of Yale University in Connecticut received eight grants totalling US $\$ 14.5$ million last year for his research into diabetes; Harold Varmus, president of the Memorial Sloan-Kettering Cancer Center, New York, received grants of $\$ 13$ million for work on cancer; and cell-death researcher John Reed of the California-based Burnham Institute for Medical Research received nearly \$11 million in 11 grants.

The data that Nature analysed include all types of NIH grant, including supplemental grants and small grants awarded to organize conferences or run training workshops. Closer inspection reveals that some researchers received a wealth of grants for precisely these reasons - Andrew Robertson, the recipient of the 32 grants, is a conference organizer for Keystone Symposia, which necessarily requires him to juggle multiple projects. His grants average out at $\$ 15,300$ each. But the multiple grants supporting some other investigators are not as immediately explicable.

Last month, advisory panels reviewing the $\mathrm{NIH}$ peer-review system recommended that researchers should devote at least $20 \%$ of their time to any project awarded a research grant (see Nature 451, 1035; 2008). This would limit the number of grants awarded per investigator to five. "Are you really able to sustain the research if you have five or ten grants?" asked $\mathrm{NIH}$ director Elias Zerhouni after a congressional hearing on 5 March. "If you are going to be a principal investigator on a grant, you have to give the time." Zerhouni told Nature he wants to place a limit on the number of grants that researchers can get each year.

"The absolute number of grants is misleading," says Sten Vermund, director of the Institute for Global Health at Vanderbilt University Medical Center in Tennessee. He received 11 grants worth $\$ 24$ million in 2007, but most of that was a single \$19-million grant to manage a global HIV-prevention trial involving hundreds of researchers working on four continents at dozens of institutions. Seven of his grants were smaller and all essentially awarded for the same thing: an international AIDS training programme. Vermund acknowledges that a former

\begin{tabular}{|c|c|c|c|c|}
\hline Principal investigator & Institution & Research type & $\begin{array}{l}\text { Number } \\
\text { of grants }\end{array}$ & $\begin{array}{l}\text { Total value } \\
\text { (US } \$ 1,000 \text { ) }\end{array}$ \\
\hline Andrew Robertson & Keystone Symposia & Conference organizer & 32 & 490 \\
\hline Terri Grodzicker & Cold Spring Harbor Laboratory & Conference organizer & 16 & 869 \\
\hline Sten Vermund & Family Health International & HIV-prevention trials & 11 & 24,132 \\
\hline John Reed & $\begin{array}{l}\text { Burnham Institute for Medical } \\
\text { Research }\end{array}$ & Cell death & 11 & 10,868 \\
\hline Jeffrey Murray & University of lowa & Birth defects & 11 & 7,060 \\
\hline Joseph McCune & University of California, San Francisco & Translational science & 9 & 25,396 \\
\hline Bert O'Malley & Baylor College of Medicine & Reproductive biology & 9 & 8,229 \\
\hline David Rawlings & Children's Hospital, Seattle & Gene therapy & 9 & 3,000 \\
\hline David Allison & University of Alabama at Birmingham & Obesity & 9 & 2,499 \\
\hline David Stewart & Cold Spring Harbor Laboratory & Conference organizer & 9 & 255 \\
\hline Robert Sherwin & Yale University & Diabetes & 8 & 14,550 \\
\hline Harold Varmus & $\begin{array}{l}\text { Memorial Sloan-Kettering Cancer } \\
\text { Center }\end{array}$ & Cancer & 8 & 13,119 \\
\hline Pamela Davis & Case Western Reserve University & Cystic fibrosis & 8 & 12,518 \\
\hline Bruce Rosen & Massachusetts General Hospital & Brain imaging & 8 & 9,063 \\
\hline John Tainer & Scripps Research Institute & DNA biochemistry & 8 & 5,375 \\
\hline Eric Nestler & $\begin{array}{l}\text { University of Texas Southwestern } \\
\text { Medical Center }\end{array}$ & Drug abuse & 8 & 5,147 \\
\hline Jennifer Grandis & University of Pittsburgh & Head and neck cancer & 8 & 3,702 \\
\hline Richard Chaisson & Johns Hopkins University & HIV, tuberculosis & 8 & 3,277 \\
\hline William Petri & University of Virginia & Intestinal parasites & 8 & 2,993 \\
\hline Joseph Vinetz & University of California, San Diego & Infectious diseases & 8 & 2,758 \\
\hline Victor Garcia-Martinez & $\begin{array}{l}\text { University of Texas Southwestern } \\
\text { Medical Center }\end{array}$ & HIV transmission & 8 & 2,463 \\
\hline Cun-Yu Wang & University of California, Los Angeles & Cancer & 8 & 1,67 \\
\hline
\end{tabular}

stint at the NIH overseeing a \$50-million grant portfolio in AIDS vaccine trials taught him a lot about how successful grant applications are packaged and marketed. "I don't want to make myself sound like a grant-writing technician, but let's be honest: that is a nontrivial part of success in biomedical research."

Other researchers seem to run "labs-on-steroids', earning multiple grants through the sheer volume and quality of their work (see 'Day in the life of an 11-grant grandee'). They argue that if they're willing to work longer and harder and still produce top research - then so be it. "Different people can achieve different things in $20 \%$ of their time. You should always reward the best science," says David Rawlings, the 51-yearold director of the Research Center for Immunity and Immunotherapies at the University of Washington in Seattle. He was supported last year by nine NIH grants worth $\$ 3$ million.

Joann Boughman, executive vice-president of the American Society of Human Genetics, says that the NIH needs to keep young researchers working in independent situations so that they can have 'eureka' moments. At the same time, she says, the agency needs to support established laboratories that produce streams of rich data, often leading to new experiments - and new grants. "The question is, do the rich get richer while the poor get poorer?" she asks.

The reality is that grantees like Vermund inhabit a different world from the vast majority of biomedical scientists. Frozen funding at the NIH is creating an environment of "anxiety and fear" where talented young researchers repeatedly have their grant proposals rejected.

Zerhouni says that the inequities between the haves and have-nots were caused by a doubling of NIH funding between 1998 and 2003. As funding levels rose, many new $\mathrm{PhD}$ positions were created. Established investigators, using data produced by the new $\mathrm{PhDs}$, were able to submit better grant proposals. But hordes of these grant-hungry PhDs were left standing when NIH funding flattened out after 2003. The agency now funds significantly more people over the age of 70 than under the age of 30 . "We're eating our seedcorn," says Zerhouni.

Changes to the NIH peer-review system will be unveiled in mid-April.

Eric Hand with additional reporting by Meredith Wadman 


\section{Day in the life of an 11-grant grandee}

John Reed's workday begins when he wakes up at 3 a.m. to write grants and papers. At 6 or 6:30, he goes for a long run, swim or bicycle ride. By his own count, he has run 20 halfmarathons and 10 marathons. Now aged 49 , he's into half-triathlons - but only because full triathlons take too much training time.

By 7:30, Reed is at work at the Burnham Institute for Medical Research in La Jolla, California, juggling roles as its president and director of a 35-person lab that specializes in cell death. If his researchers need him urgently, they e-mail a secret address that goes directly to him. They each have weekly goals that must be met, and progress is measured with project-management software. "It's a no-nonsense, get-the-jobdone, focused environment," Reed says.

On many evenings he has business dinners and meetings to attend. Every other evening, he goes home to spend time with his family. At weekends, he sleeps in - until 4:30 a.m. Kenneth Yip, a 28-year-old postdoctoral researcher from Canada, joined the lab two years ago knowing that working with Reed would help him to build an attractive CV.

"I don't know many principal investigators at that level who have washboard abs," Yip says. "He does everything $100 \%$ - which is $200 \%$ for the rest of us."

Reed's results speak for themselves. Between 1995 and 2005, he was the most highly cited author in all of cell biology, with 23,729 citations, according to Thomson's ESI ranking. His lab has averaged one paper per person per year.

His productivity has been rewarded with support from the US National Institutes of Health (NIH). In 2007, he received $11 \mathrm{NIH}$ grants worth almost $\$ 11$ million. He says he deserves them all. And he doesn't support a cap to the number of grants permitted per researcher. "The evidence is that some labs and some people can handle a larger portfolio," Reed says. "I don't think we should apply a one-size-fits-all mentality."

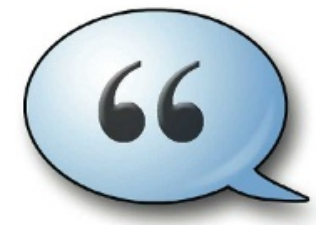

HAVE YOUR SAY

Comment on any of our news stories, online.

www.nature.com/news

\section{The Solar System's first breath}

\section{HOUSTON, TEXAS}

Scientists have made the crucial measurement of oxygen composition at the birth of the Solar System. The discovery fulfils the top science priority of the NASA Genesis probe, which slammed into the Utah desert in 2004 on its return to Earth when its parachute failed to open.

"Despite crashing, all the major science objectives of Genesis will be met," says Kevin McKeegan, a cosmochemist at the University of California, Los Angeles. He announced the finding on 10 March at the Lunar and Planetary Science Conference in Houston, Texas.

The finding that the Sun is relatively richer than Earth in oxygen-16, the most common oxygen isotope, contradicts the conventional wisdom that Earth has the same oxygen isotope composition as the Sun. The discovery also gives researchers a reference point for the oxygen composition at the origin of the Solar System. Genesis trapped the stream of ionized particles known as the solar wind - which, because it emanates from the relatively unchanged outer layers of the Sun, is thought to carry primordial oxygen among its elements.

Oxygen-16, with eight protons and eight neutrons, comprises $99.8 \%$ of the oxygen on Earth. There are smaller amounts of oxygen-17 and oxygen-18, whose proportions vary throughout the Solar System. Scientists have measured slightly different proportions on Earth, Mars, the Moon and in meteorites, as if each place has its own oxygen fingerprint. "We had a map for oxygen isotopes," says McKeegan. "But we didn't know which way was up."

Researchers have gone to great lengths

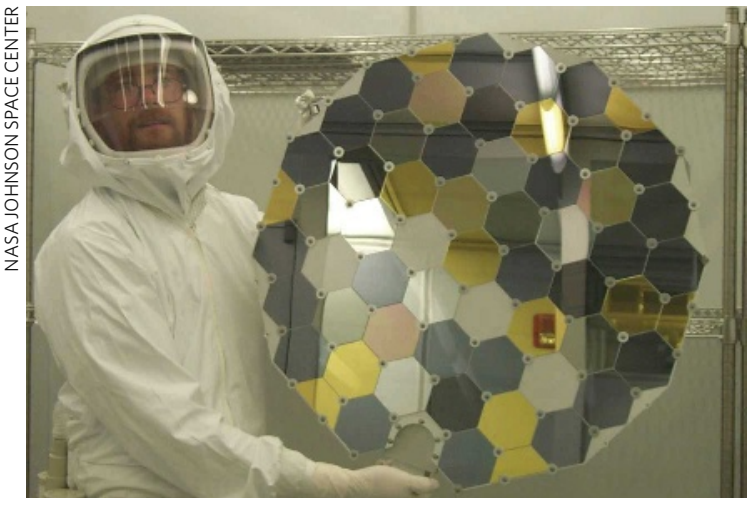

Genesis' collectors trapped atoms in the solar wind. to try to discover the original proportion of oxygen isotopes in the Sun. Two rival groups published contradictory results from analyses of lunar soils, which are thought to contain embedded solar oxygen as the Moon lacks an atmospheric shield against the solar wind (see Nature 440, 751-752; 2006). One of those researchers, Marc Chaussidon, is pleased that the new findings could settle the debate.

"There has been this question for years," says Chaussidon, a cosmochemist at the Research Centre for Petrochemistry and Geochemistry in Nancy, France. "Everybody would have bet that the Sun had the same composition as Earth and the meteorites. In fact, Earth is not like the Sun."

The result represents a triumph for the Genesis scientists, who have salvaged what they could from the wreck, including isotopic analyses of noble gases (A. Meshik et al. Science 318, 433-435; 2007). But oxygen is tougher to measure, as it is so plentiful and reactive. McKeegan and his group used a mass spectrometer on a 3millimetre-square section of a silicon wafer containing oxygen from the solar wind.

Using a beam of caesium ions, the researchers eroded the top 20 nanometres of the sample to remove any contamination by Earth-based oxygen. Then, in a vacuum, they measured the isotopic composition of the Sun's oxygen, using the ion beam to knock the atoms loose from the silicon trap, and found a greater proportion of oxygen-16 than on Earth.

The result raises more questions, says Chaussidon. Now, scientists need to understand why Earth's oxygen composition is different from the Sun's, and what chemical processes caused the change. Whatever the process, it would have sucked out oxygen-16 while the gas of the proto-Solar System condensed into solid grains that coalesced into the planets.

It would also have been one of the very first things to happen in the 4.5685-billionyear-old Solar System. Chaussidon says the mystery process would have stripped away the oxygen-16 within the system's first few million years of existence.

Eric Hand 